Bond University

Research Repository

\title{
Security Deficit
}

\section{Dellios, Rosita}

\section{Published in:}

The Palgrave Encyclopedia of Global Security Studies

DOI:

10.1007/978-3-319-74336-3_281-1

\section{Licence:}

Other

Link to output in Bond University research repository.

Recommended citation(APA):

Dellios, R. (2019). Security Deficit. In S. Romaniuk, M. Thapa, \& P. Marton (Eds.), The Palgrave Encyclopedia of Global Security Studies Palgrave Macmillan. https://doi.org/10.1007/978-3-319-74336-3_281-1

\footnotetext{
General rights

Copyright and moral rights for the publications made accessible in the public portal are retained by the authors and/or other copyright owners and it is a condition of accessing publications that users recognise and abide by the legal requirements associated with these rights.
}

For more information, or if you believe that this document breaches copyright, please contact the Bond University research repository coordinator. 


\section{Security Deficit}

- Rosita Dellios, Bond University

Key Words: human security, non-traditional security threats, 'military operations other than war', multi-actor approach

A security deficit essentially refers to a threat. It can be on different scales from sub-national to national and global. Threats come in various forms, not only military, but also societal, economic, political and cultural. Further adding to the complexity of what is a threat - and hence what constitutes a security deficit - the scale and form of threats need not be distinct but can impact on, or overlap, one another. The impact of climate change, for example, may be analysed at global and local levels, as well as its economic and policy implications. Unlike traditional threats, where military force is used against an adversary, non-traditional security threats - like climate change, transnational crime, politically motivated violence or economic crises - are often depicted in human security terms.

Human security itself is a broad term, the referent being the human rather than the state, and needs to be viewed within particular contexts. One context is that of non-state armed groups. These include terrorists, insurgents, militias, and criminal organizations. They not only pose a military threat to states and their neighbouring regions but, from the human security perspective, to local communities. Indeed, research suggests that "the most pervasive threat from non-state armed groups is to the human security of local civilians" (Englehart, 2016). This is illustrated by the activities of Islamic State (IS). Among other violations, its genocidal aggression against Iraq's Yazidi minority in 2014 has been well documented (UN, 2014). Englehart (2016) points out that non-state armed groups can even be a source of security, as exemplified by the Kurdish peshmerga militias having assisted Yazidis fleeing IS. This was enabled by state intervention in the form of US airstrikes against Islamic State, showing state and non-state actors have their distinctive and complementary roles to play.

Indeed, the United States may be regarded as the main supplier of the security to other states in what Reveron (2016) refers to as "exporting security". This goes beyond the application of its warfighting capabilities and enters the realm of non-warfighting activities. These are aimed at reducing security deficits worldwide, including humanitarian assistance and other 'soft power' expressions of military cooperation. Variously termed 'military operations other than war' (MOOTW), 'peace support operations' (PSO), and non-war missions, they provide public goods to the international community.

China, too, has emphasized its MOOTW (State Council Information Office, Part V), having engaged in counter-terrorism and anti-piracy efforts, UN peacekeeping, and rescue operations in disaster or war zones. China is likely to expand its stability-building efforts as its 
transregional megaproject, the Belt and Road Initiative (the Silk Road Economic Belt and the Maritime Silk Road), advances in the building of infrastructure such as ports, railways and telecommunications. Otherwise, transaction costs could outweigh anticipated profits (Swanström, 2015: 7) and economic development would be at the mercy of poor governance in host countries. As Wang (2017) puts it: "Without sound institutions to ensure the proper distribution and use of infrastructure funding, investment projects may function as a resource curse ..." Thus the security deficit in weak states may be traced to ineffective governance, corruption and lack of institutions that hamper human security across many contexts, including health, education, human rights, and peace-based economies. The traditional concept of security as state-based fails to manifest in these cases of fragile states. They do not have the means to create security for themselves or their people. Instead, as Gjørv (2012) argues, a multi-actor approach in addressing security deficits in such cases is needed.

This concept of security, in which non-war missions are pursued and are often characterised as cooperation between military and civilian agencies, allows for a coincidence of interests between the state and the individual or community. In other words, a positive security concept emerges in which external and internal actors, military and civilian sectors, find nonviolent ways of mitigating security deficits. Such a view links a state's internal security to regional stability beyond it - and thence to global security in this interdependent world. Nonetheless, a security deficit can legitimately be analysed at the national level. For example, the United States is seen as having a security deficit in that allocated resources are not keeping up with changes in the strategic environment posed by Russia, China and upheaval in the Middle East (Ochmanek et al., 2015); as is Sweden which fears Russian expansionism (Anthony \& Weintraub, 2018). However, the transnational nature of 21 st century threats ensures a common ground for the quest for a more stable world order. This includes cooperation on cyberspace, which is notoriously insecure and prone to 'hacking'; transnational crime and terrorism; health and the environment; energy and resources, as well as economic sustainability.

While the United States has been advised to treat security deficits as challenges - including those that "come from strong states that break the rules, and weak ones that cannot enforce them" - it also needs to be mindful of the need to "promote the development of new norms in domains where these do not yet exist [or are only just emerging], such as cyber and climate management" (Dobbins, 2015). Even more proactive is the multi-actor approach of the United Nations that has brought together governments, businesses and civil society to achieve the Sustainable Development Agenda by 2030 that seeks the achievement of 17 'Goals' from eradication of extreme poverty, to gender equality and social justice (UN, 2018). These address the human dimension of security and, in doing so, facilitate other levels of security, including that of the state (see Supranational Actors).

To conclude, a security deficit is a way of talking about threats beyond the traditional statebased format in which the military is used for deterrence or defence. While not denying this state perspective, it adds to the understanding of what constitutes security by referring to the human level and the intricate web of vulnerability in which one set of dangers cascades into another. Equally, the pursuit of security through improved institutions and peace-building 
also addresses security deficits in a positive sense of building security rather than simply focusing on averting or overcoming threat. Ultimately, multi-actor and multi-sector action is needed as a more effective strategy for overcoming a deficit in security.

\section{Further Reading}

Collins, A. ed. (2016). Contemporary Security Studies, 4th ed., Oxford: Oxford University Press.

\section{References}

Anthony, I. \& Weintraub, C. (2018, March). Closing Sweden's Military Security Deficit: the National Debate on NATO Membership, Research Paper 144, NATO Defense College, http://www.ndc.nato.int/news/news.php?icode $=1144$

Dobbins, J., Solomon, R.H., Chase, M.S., Henry, R., Larrabee, F.S., Lempert, R.J., Liepman, A., Martini, J., Ochmanek, D., \& Shatz, H.J. (2015). Choices for America in a Turbulent World: Strategic Rethink, Santa Monica, CA: RAND Corporation, 2015. https://www.rand.org/pubs/research_reports/RR1114.html.

Englehart, N.A. (2016, May). Non-state Armed Groups as a Threat to Global Security: What Threat, Whose Security? Journal of Global Security Studies, Volume 1, Issue 2: 171-183, https://doi.org/10.1093/jogss/ogw003

Gjørv, G. (2012). Security by any other name: Negative security, positive security, and a multi-actor security approach. Review of International Studies, 38(4), 835-859. Retrieved from http://www.jstor.org.ezproxy.bond.edu.au/stable/41681492

Ochmanek, D., Hoehn, A.R., Quinlivan, J.T., Jones, S.G. \& Warner, E.L. (2015). America's Security Deficit: Addressing the Imbalance between Strategy and Resources in a Turbulent World: Strategic Rethink, Santa Monica, CA: RAND Corporation, https://www.rand.org/pubs/research_reports/RR1223.html

Reveron, D.S. (2016). Exporting Security: International Engagement, Security Cooperation, and the Changing Face of the U.S. Military, 2nd ed., Washington, DC: Georgetown University Press.

State Council Information Office, PRC (2015, May). China's Military Strategy, white paper, Beijing, http://english.chinamil.com.cn/news-channels/2015-05/26/content_6507716.htm

Swanström, N. (2015, September). China's New Silk Road, A Security Deficit?, Dragon News, No. 3, Swedish Chambers of Commerce, Hong Kong and China, http://isdp.eu/content/uploads/publications/2015-Swanstrom-China-New-Silk-RoadCommentary.pdf 
United Nations (2014). Report on the Protection of Civilians in Armed Conflict in Iraq: 6 July - 10 September 2014, Baghdad: UNAMI/OHCHR, https://www.ohchr.org/Documents/Countries/IQ/UNAMI_OHCHR_POC_Report_FINAL_6J uly_10September2014.pdf

United Nations (2018). Sustainable Development Goals, https://www.un.org/sustainabledevelopment/

Wang, X. (2017, 17 November). One Belt, One Road's Governance Deficit Problem: How China Can Ensure Transparency and Accountability, Foreign Affairs, https://www.foreignaffairs.com/articles/east-asia/2017-11-17/one-belt-one-roads-governancedeficit-problem 